- DOI: 10.31866/2410-1311.38.2021.245712

УДК 78.036.9:[008:316.347(=013:73)"18"

\title{
- СОЦІАЛЬНИЙ АСПЕКТ ВИНИКНЕННЯ БЛЮЗУ ЯК ПРОВІДНОГО ЯВИЩА АФРОАМЕРИКАНСЬКОЇ КУЛЬТУРИ ХІХ СТОЛІТТЯ
}

\section{- Журба Яніна Олексіївна}

- Керівник Школи джазу Володимира і Яни Журби,

ORCID: 0000-0002-8466-4888, e-mail: yanazhurba7@gmail.com,

Центр культури та мистецтв Дніпровського району м. Києва,

вул. Алматинська, 109, Київ, Україна, 02090

\section{- Для цитування:}

Журба, Я.О. (2021). Соціальний аспект виникнення блюзу як провідного явища афроамериканської культури XIX століття. Питання культурології, (38), 97-108. doi: https://doi.org/10.31866/24101311.38.2021.245712.

\section{- Анотація}

Мета статті — виявити та дослідити соціальний аспект виникнення блюзу як провідного явища афроамериканської культури XIX ст. Методологічна база дослідження ґрунтується на застосуванні універсальних наукових методів - системного аналізу, порівняння та узагальнення, що забезпечило різнопланове вивчення об'єкта і предмета дослідження. Наукова новизна роботи полягає в тому, що соціальний аспект виникнення блюзу якпровідного явища афроамериканської культури XIX ст. вперше висвітлено в контексті культурології. Висновки. В дослідженні визначено, що соціальний аспект відіграє провідну роль в процесі виникнення блюзу. Історичні умови стали причиною фрормування специфічних характеристик соціальних процесів, що мали вагоме значення в контексті буття афроамериканської спільноти XIX ст. на території США. Встановлено, що саме зміни в соціальному просторі, які відбулися після офіційного скасування рабства, стали каталізатором народження нових форм в афроамериканській культурі. Специфіка зазначених соціальних процесів полягала в особливостях ресоціалізації афроамериканців у суспільстві США, соціальній ізоляції, що великим чином утискала явище соціальної творчості в афроамериканському середовищі, аспекті перманентного опору та боротьби афроамериканців за свої права в американському соціумі, що сприяв збереженню сталості характерних елементів афроамериканської культури. Зазначені характеристики сприяли виділенню афроамериканської культури на тлі культури США, а надалі й світової культури. Саме цей аспект необхідно визначити як головну причину широкомасштабного розповсюдження та впливу явищ афроамериканської культури, зокрема блюзу, на появу та становлення панівного пласту музичної культури, який визначається як неакадемічна музика XX ст.

Ключові слова: афроамериканська культура XIX ст.; блюз; передумови виникнення блюзу; соціальний аспект 


\section{- Вступ}

Блюз $є$ одним із найважливіших внесків афроамериканської культури у світову музичну скарбницю. Враховуючи той фракт, що історія його виникнення тісно пов'язана із соціальними процесами, що відбувалися в американському суспільстві у XVII-XIX ст., ми можемо вказати на вагоме значення соціального аспекту в переліку передумов його появи.

Сьогодні зазначене питання в культурологічному ракурсі досліджено недостатньо. Більшою мірою дослідження проведені в галузі мистецтвознавства та музикознавства. У фрормі екскурсу по музичним жанрам, витоком яких був блюз проводить дослідження А. Тягіна (2019). Певні історичні аспекти появи блюзу висвітлені в роботі А. Алексєєвої (Алексеева, 2018). Мистецтвознавчий аспект походження блюзу досліджено в роботах В. Конен (1984), Д. Коллієра (Коллиер, 1984). В музикознавчому ракурсі проведене дослідження блюзу в роботі М. Докучаєвої (Докучаева, 2020). Але вказана проблематика потребує поглибленого вивчення через вагомість предмету дослідження в межах світової культури, зокрема неакадемічної музики XX ст., що свідчить про актуальність обраної тематики статті.

\section{Мета статті}

Мета статті - дослідити соціальний аспект передумов виникнення блюзу та виявити його роль в межах афроамериканської культури XIX ст. Методологічна база дослідження ґрунтується на застосуванні універсальних наукових методів - системного аналізу, порівняння та узагальнення, що забезпечило різнопланове вивчення об'єкта і предмета дослідження. Дослідження окресленої проблематики має важливий характер з причини широкого спектра впливу афроамериканської культури, зокрема блюзу на появу та становлення світової музичної культури.

\section{- Виклад матеріалу дослідження}

3 появою першого африканця-раба на території США почалася віха історії нового соціального класу американського соціуму. Його провідними ознаками стали слова рабство, знущання, відсутність людських прав тощо. Але необхідно зауважити, що попри всі страждання та злидні афроамериканської спільноти часів панування рабства в Америці, саме зазначена «соціальна трагедія» стала причиною широкого впливу афроамериканської культури на сучасну культуру, зокрема музику, моду, кінематограф. А приклад боротьби афроамериканців за свої цивільні права і сьогодні надихає людей у всьому світі.

Подібна ситуація була обумовлена насамперед історичними умовами. Період, який підлягає висвітленню у зв'язку з обговорюваним питанням, що пов'язане з передумовами появи блюзу, визначається як проміжок часу від початку XVII cт. до кінця XIX ст. ${ }^{1}$ Оскільки блюз є невід'ємною частиною афроамериканської культурної традиції, то цілком логічним буде шукати відповідь на питання,

Попри той фракт, що, починаючи з 1808 р., торгівля рабами перейшла в нелегальний простір, ми беремо до уваги історичний проміжок аж до появи зазначеного музичного явища світової культури. 
що досліджується, в контексті історії існування афроамериканців на території США. Початок зазначеного періоду обумовлений появою в Америці перших афроамериканців, які були привезені туди як рабська робоча сила. О. Єфімов зазначає дату 1619 р., що вказує час, коли перша партія африканців була привезена «в англійські колонії Північної Америки», тому саме цю дату ми визначимо як початкову точку періоду, що висвітлюється (Ефимов, 1958, с. 26). Північна Америка тих часів була досить невибагливим місцем, особливо для тих, хто мав темний колір шкіри. Описуючи умови, в яких перевозилися африканці до Нового світу, А. Єфрімов вказує, що вони були справді жахливими: «Відстань між палубами зазвичай становила 3 фути 3 дюйми (трохи більше метра). Туди рабів заганяли батогами, причому змушували лягати щільно один до одного. В таких умовах невільники проводили весь багатоденний перехід з Африки в Америку» (Ефимов, 1958, с. 33). Офіційно афроамериканці не були рабами, а мали довгостроковий контракт без права на розірвання. 3 часом такі контракти перетворилися на довічні та спадкові для дітей, які були народжені від жінок, з якими був укладений подібний договір. Після скасування рабства ситуація лише погіршилася, оскільки рабів тепер ввозили контрабандою, що ускладнило умови їх пересування та значно підвищило відсоток смертності. Натовп новоприбулих африканців являв собою безмовну та безлику масу, учасників якої ще на початковій стадії «перемішували». Метою подібного змішування було виключення потенційних змов. У Новому світі привезені африканці існували в абсолютно ворожому для себе середовищі. Однак попри цей факт або навіть завдяки визначеній характеристиці, їх новонароджена культура зберегла риси свого етнічного походження.

Як відомо, колективні пісні $є$ доволі важливим чинником підвищення продуктивності праці. М. Стернс (1970) зазначає: «Функція всякої робочої пісні (як вказує сама назва) суто утилітарна - вона полягає в координації зусиль працюючих людей». 3 цієї причини невід'ємною частиною життя афроамериканців XVIII ст. були твори, що супроводжували роботу. Основним заняттям рабів було сільське господарство, тому найбільший відсоток становили робочі пісні ${ }^{2}$, які виконували в полі. Існували й інші підвиди робочих пісень афроамериканців, що класифікувалися за приналежністю до роботи‥ Зауважимо, що музика є досить суттєвим чинником підтримки не лише морального, а й фрізичного стану людини. Окрім теорій древніх фрілософів ${ }^{4}$, існують відомі сучасні дослідження, які доводять подібне твердження. Найбільш перекликається з ним методика С. Шушарджана, який стверджує, що кожен звук залежно від його тембру і висоти впливає на органи людини та пропонує заняття вокалотерапією. Науковець зауважує, що музика має здатність впливати на організм не тільки через слухове сприйняття, а й через шкіру (Шушарджан, 2005, с. 204). Зазначений процес відбувається

\footnotetext{
2 Зв'язок блюзу насамперед із робочими піснями, ніж зі спіричуелом, визначає Д. Коллієр (Коллиер, 1984 , с. 75$)$.

3 Будівництво доріг, робота на суднах та рудниках.

4 Як відомо, Гіппократ пропонував використовувати музику нарівні з ліками, Демокріт радив слухати музику при важких інфекційних захворюваннях, про лікувальні особливості музики писали Піфрагор, Арістотель та Платон.
} 
через вплив звукових хвиль на віброрецептори, причому при певній частоті починає діяти навіть протибольова система. Є. Яковлєва та Е. Кубасова (Яковлева \& Кубасова, 2011) вказують, що за допомогою сучасних наукових технологій встановлено, що музика здатна позитивно впливати на певні медичні показники людини (с. 65). Відомі також і дослідження інших науковців: І. Мельнік та Є. Гавріліна, Р. Блаво, Б. Харріса та ін. Тому ми також можемо зробити припущення, що саме критична та практично життєва необхідність в існуванні творчого, зокрема музичного компонента в укладі життя афроамериканців, стала причиною збереження самобутності їх етнічних традицій. Подібний тісний зв'язок музичної культури з побутом виникав через потребу полегшення рабського життя. Також до цього твердження можна долучити вислів К. Биховського (Быховский, 2004), який вказує, що, на відміну від сучасного суспільства, в якому музика асоціюється «насамперед зі сфрерою мистецтва, з художньою творчістю, - 3 моменту свого виникнення і протягом багатьох століть» вона «виконувала безліч функцій, що лежать далеко за межами власне естетичних пошуків людини» (с. 3). Науковець зауважує, що «музика спочатку була залучена в практики, більш пов'язані з виживанням» (Быховский, 2004, с. 3). Крім того, незаперечним фрактом $є$ і те, що вказана музична культура спиралася на закони саме африканської музики. Про це свідчать характерні риси композицій, які пов'язані із законами побудови африканської музики, а саме: яскраво виражена ритмічна основа, переклик між солістом та групою, застосування засобів shout (шаут), holler (холлер), панування в мелодиці блюзового строю, спирання на остинатність у побудові музичного матеріалу тощо (Овчинников, 1994). Ці твори склали основний пласт музичної культури африканців-рабів на території США та стали своєрідним проявом масового мистецтва афроамериканської спільноти. Подібне твердження має важливе значення, оскільки широке масове розповсюдження відіграє велику роль у процесах довготривалого існування явищ культури та масштабу їх впливу. Музична культура для африканської раси відігравала значущу роль, оскільки їй притаманна величезна енергетика, що бере початок від магічних африканських обрядів. Саме завдяки визначеним чинникам самобутня африканська культура проявила небувалу стійкість у непростих історичних та соціальних умовах, що склалися щодо неї протягом XVII-XIX ст. на території США.

Враховуючи вищеописану історичну ситуацію, необхідно зазначити, що процес соціалізації африканців у суспільстві США мав нестандартний характер 5 . Подібне твердження ми можемо зробити через особливості соціальної групи, до якої належали афроамериканці. Зауважимо, що поняття соціалізації за час свого існування набуло трансформацій та отримало певне розширення. Починаючи з кінця XIX ст., цей термін зустрічається в роботах Ф. Гіддігса, Г. Тарда та ін., які трактували його як процес становлення та розвитку особистості. Надалі воно було конкретизовано та визначено як процес накопичення індивідом досвіду, що

5 Зазначимо, що в цьому разі ми маємо справу із вторинною соціалізацією, якщо йдеться про період після офіційного скасування рабства, або з ресоціалізацією, якщо йдеться про період привезення афроамериканців у Новий світ як рабів (Перинская, 2005, с. 161). Але для спрощення термінології, що застосовується, надалі буде використовуватися термін «соціалізація». 
відповідає його соціальній ролі (Смелзер, 1994). Під час подальшого розвитку воно набуло розширення та в його межах було виділено дві провідні функції засвоєння, а також відтворення соціального досвіду (Андреева, 2001, с. 276). В роботах сучасних науковців до вищезазначених двох фрункцій було долучено третю - соціальну творчість. Як пише І. Сердюк (2006), соціальна творчість це активна соціальна діяльність «у різних сферах суспільства», що обумовлена «прагненням до змін і перетворень» (с. 92-93). Автор також вказує, що серед головних ознак соціальної творчості можна визначити прагнення індивіда до самовизначення та оновлення буття, бажання «змінити щось хоча б частково для досягнення визначеного суспільством критерію нормального існування» (Сердюк, 2006, с. 89). Зауважимо, що перша визначена характеристика $\epsilon$ індивідуальною формою соціальної творчості, а друга - колективною, оскільки в цьому процесі задіяний не лише індивід, а й соціум. Проєктуючи зазначене поняття на афроамериканську спільноту XVII-XIX ст., слід вказати, що соціальна діяльність індивіда, а саме африканського раба, була певним чином пригнічена. Причиною цього були особливості процесу соціальної взаємодії. Спираючись на дослідження В. Ковальова (Ковалев, 2015) «Типы социального взаимодействия и социальное творчество», в якому автор визначив п'ять рівнів соціальної взаємодії, зазначимо, що соціальні взаємини, складовою яких була афроамериканська спільнота, стосуються II рівня, що характеризується «наявністю односпрямованого впливу соціуму на індивіда або навпаки» (с. 33). Тут є доречним напрям соціального впливу від соціуму до індивіда або групи індивідів. Саме тому сфери соціальної діяльності афроамериканців, що є групою індивідів, були вкрай обмеженими за своїми масштабами. Водночас для афроамериканців був завжди визначальним чинник непокори та боротьби, що перегукується з другою основоположною характеристикою соціальної творчості та визначається як «прагнення до змін і перетворень» (Сердюк, 2006, с. 92-93). Отже, ми можемо визначити, що подібне утискання простору для соціальної творчості при наявності яскраво вираженого прагнення до змін панівного устрою вимагало певної розрядки та переходу із внутрішнього стану до зовнішнього.

Як зазначає І. Сердюк (2006), соціальна творчість охоплює всі види творчості. Сьогодні науковцями визначені такі різновиди творчості: технічна, наукова, літературна, образотворча, музична, навчальна, ігрова, комунікативна, побутова, військова, управлінська, ситуаційна (Коваленко, 2009, с. 37). Зважаючи на характеристики різновидів соціальної творчості, найширшою сферою, де раб-афроамериканець не зазнавав утиску, була музична творчість. Подібний чинник був зумовлений насамперед тим, що вона не була визначальною у класовій належності в суспільстві. Така творча діяльність не потребувала ніяких допоміжних засобів, порівнюючи з, наприклад, образотворчою діяльністю. Аналізуючи інші напрями потенційно можливих різновидів творчості афроамериканців-рабів, зауважимо, що побутова творчість раба була вкрай обмеженою, оскільки все життя афроамериканця часів рабства складалося з роботи, а на побут не вистачало сил та часу. 3 цієї ж причини в бутті афроамериканців $є$ значно скороченими ті різновиди творчості, що здаються найприроднішими для існування індивіда в соціумі, а саме ситуаційна та комунікативна. 
В процесі вивчення зазначеного питання цілком доречно звернути увагу на зв'язок творчості та праці, зокрема фрізичної. Подібне твердження висловлюють автори у роботі «Філософрія» і стверджують, що «праця і творчість» «взаємозв'язані» (Горлач, 2000, с. 538). Крім того, автори ідентифікують здібності до праці та здібності до творчості. Зрозуміло, що подібне зауваження потребує коректного трактування, оскільки необхідно розділяти працю за примусом та за власним бажанням. Також до різних категорій належать праця, спрямована на виживання, та праця, присвячена власному розвитку та удосконаленню здібностей індивіда. Автори визначають, що на ступінь зв'язку визначених понять впливають чинники «моральної атмосфрери», умови «життя індивіда» та рівень демократизації соціуму (Горлач, 2000, С. 538-539). Враховуючи обставини існування афроамериканця-раба, ми можемо зауважити, що подібний зв'язок був на досить низькому рівні. Але, спираючись на аналіз соціально-історичної ситуації, що склалася у визначений період, ми вважаємо за потрібне враховувати фракт наявності такого зв'язку. Компенсацією невеликого рівня зв'язку між працею та творчістю стало масштабне розповсюдження певного укладу життя афроамериканця-раба, який був нерозривно пов'язаний із перманентною працею. Визначений чинник формував певну колективну свідомість афроамериканської верстви населення, що була спрямована на творчий процес. Процес соціальної творчості підневільного афроамериканця тривалий час практично повністю складався, окрім праці, з музичної творчості. Підсилюючим чинником було також і те, що остання була невід'ємною складовою процесу роботи. Тісний зв'язок, який був зумовлений соціально-історичною ситуацією, попри важкі побутові обставини став однією з головних причин закріплення творчого процесу як провідної риси афроамериканської культури. Зауважимо, що саме завдяки тому, що буття афроамериканців завжди було пов'язаним із творчістю, зокрема з музичною, не був втрачений їх тісний зв'язок зі своїм етнічним корінням, внаслідок чого відбулося втілення його характерних рис та особливостей у феномені блюзу. Як влучно зазначає Н. Лисікова (Лысикова, 2015), «завдяки освоєнню народної культури носій усвідомлює свою приналежність до конкретного соціокультурного середовища, ідентифікує себе з ним» (с. 32).

Зауважимо, що африканці ніколи не були покірними рабами. Історія афроамериканців наповнена фрактами про постійні повстання (найбільші під керівництвом Габріеля, відомого як Г. Проссер, Като, Д. Везі, Н. Тьорнера та ін.), деякі з яких відбувалися ще при пересуванні рабів на кораблях. Відомо, що існував особливий різновид страхування для рабовласників, які перевозили рабів, що передбачав покриття збитків через бунт рабів. Крім того, попри жорстокі покарання, серед афроамериканців відбувалися постійні втечі, в яких брали участь навіть жінки та діти. Вдаючись до аналізу проявів боротьби афроамериканців за свої права у більш пізній час та на більш високому ступені соціального розвитку ${ }^{6}, \epsilon$ цілком доречною, як приклад, діяльність певної кількості організацій, що були спрямовані на боротьбу за права темношкірого населення США. Йдеться

6 Йдеться про період після не тільки офріційного скасування рабства, а і після його остаточного зникнення. 
про діяльність Національної афроамериканської ліги (НАЛ), що була створена журналістом Т. Т. Форчуном у 1887 р. (Воробьев, 2018). Або організацію «Ніагара», що надалі перетворилася у «Національну асоціацію сприяння прогресу кольорового населення» (НАСПКН), до складу якої увійшла значна частина афроамериканців із «Ніагари» та білих представників прогресивного руху (Воробьев, 2017). Саме завдяки діям подібних організацій афроамериканцям зрештою вдалося досягти цивільного і політичного рівноправ'я у 60-х рр. XX ст. Подібні фракти свідчать про те, що попри певну низку проблем у процесі організації роботи вказаних установ, як-от недостатнє фрінансування, постійне існування в конфліктному середовищі, не налагоджена робота фріліалів вищезгаданих організацій тощо, елемент незламного протистояння посідає провідну позицію в контексті афроамериканського соціального буття, що стає досить потужним каталізатором для створення подібних соціальних угруповань. Звертаючись до вивчення історичної ситуації Америки XVII-XIX ст., безумовно, необхідно відзначити нерівномірність розподілу центрів вказаної боротьби на території країни. Йдеться про різницю між соціальною ситуацією, що складалася на Півночі та Півдні. Подібний фракт пояснюється різницею в процесах американських земель, оскільки колоністи Півночі та Півдня певним чином відрізнялися, що зумовило розбіжності у формуванні правил та умов соціального укладу. Але це впливало лише на ступінь прояву відчуження та утискання афроамериканців, тоді як сутнісний зміст окресленого питання був ідентичним. Зазначимо, що саме визначене домінування аспекту рішучої незгоди та боротьби назавжди надали афроамериканській культурі яскраві відтінки соціального протесту. До того ж ми можемо трактувати роль визначеної характеристики як основоположну, оскільки людина з темним кольором шкіри весь час була вимушена протиставляти себе навколишньому соціальному середовищу. Подібне протистояння відтворилося і в провідній характеристиці музичної культури афроамериканців, зокрема блюзу, що визначається нами як маргінальність.

Ускладнення розвитку соціальної творчості в інших напрямах призводила до підвищення активності в тому напрямі, в якому така творчість була можлива. Тому в контексті афроамериканської культури музична творчість набуває ознак важливого соціального чинника, що набув стратегічного значення у світових соціальних відносинах. Саме музична творчість як єдиний можливий різновид соціальної творчості стала головним інструментом афроамериканців у процесі змін умов свого соціального існування, оскільки, як пише В. Ковальов (Ковалев, 2016), «у практичному перетворенні дійсності мистецтво відіграє важливу роль» (c. 25).

Крім того, під час виявлення передумов виникнення блюзу важливо зазначити фракт того, що довгоочікуване офріційне скасування рабства у США не принесло афрроамериканцям практичного полегшення. Незважаючи на певну низку змін ${ }^{7}$, середньостатистичний афроамериканець не отримав очікуваного ним розширення сфер соціальної творчості. Подібне емоційне розчарування без-

\footnotetext{
7 Йдеться про Чотирнадцяту (1866) та П'ятнадцяту (1870) поправки до федеральної Конституції, що проголошували афроамериканців громадянами та надавали їм право голосу.
} 
умовно потребувало певної візуалізації. Оскільки саме «музика... відображає емоційний світ людей», такою візуалізацією і став блюз (Непомнящих, 2014, c. 272).

\section{- Висновки}

Отже, соціальний аспект займає центральну позицію в процесі виникнення блюзу. Певні історичні умови стали причиною появи соціальних процесів, які відігравали провідну роль в межах буття афроамериканської верстви населення. Зокрема: особливості процесу ресоціалізації афроамериканців в американському суспільстві, що були зумовлені маргінальним становищем афроамериканської соціальної групи в складі американського соціуму; соціальне відмежування, що певним чином утискало явище соціальної творчості в афроамериканському середовищі; чинник постійного опору та боротьби афроамериканців за свої права в американському суспільстві, що відігравав значущу роль у процесі збереження характерних елементів своєї культури. Крім того, необхідно зауважити, що саме через певні зміни в соціальному становищі афроамериканців, які відбулися після скасування легального рабства, з'явилася потреба нових форм у контексті афроамериканської культури. Зазначені соціальні процеси були носіями ознак, які великою мірою виділяли афроамериканську спільноту та відповідно ії культуру на тлі культури США та надалі в контексті світової культури, що і стало причиною широкого розповсюдження та впливу блюзу на формування неакадемічної музичної культури XX ст.

\section{- Список використаних джерел}

Алексеева, А. А. (2018). Истоки возникновения блюза и его распространение. Студенческая наука и XXI век, 2-2, 14-16.

Андреева, Г. М. (2001). Социальная психология. Аспект Пресс.

Быховский, К. Б. (2004). Музыка в современных социальных дискурсах: принципы и основные векторы культурологического анализа [Автореферат диссертации на соискание ученой степени кандидата культурологии, Московский педагогический государственный университет].

Воробьев, Д. Н. (2017). Деятельность организации «Ниагара» и появление негритянского протестного движения в США (1905 - 1909). Вестник Брянского государственного университета, 4(34), 50-57.

Воробьев, Д. Н. (2018). Национальная афроамериканская лига: на заре негритянского протестного движения в США (1887-1894). Известия Саратовского университета. Новая серия. Серия: История. Международные отношения, 18(1), 84-89.

Горлач, М., Кремень, В., \& Рибалко, В. (Ред.). (2000). Філософрія. Консум.

Докучаева, М. Н. (2020, 10 марта). Музыкальный феномен блюза. В Л. М. Артамонова, В. И. Ионесов, \& М. В. Курмаев (Ред.), Национальное культурное наследие России: региональный аспект, Материалы VIII Всероссийской научнопрактической конференции, Самара (с. 256-260). Самарский государственный институт культуры.

Ефимов, А. В. (1958). Очерки истории США 1492-1870. Учпедгиз. 
Ковалев, В.Г. (2015). Типы социального взаимодействия и социальное творчество. Вестник Московского городского педагогического университета. Серия «Философрские науки», 2(14), 30-41.

Ковалев, В. Г. (2016). Роль искусства в социальном творчестве. Педагогика искусства, 2, 25-30.

Коваленко, Т. М. (2009). Творчість і креативність - риси майбутніх фрахівців у вищій економічний освіті. Вісник НТУУ «КПІ». Філософрія. Психологія. Педагогіка, 3(27), 2, 35-41.

Коллиер, Д. Л. (1984). Становление джаза. Радуга.

Конен, В. Д. (1984). Рождение джаза. Советский композитор.

Лысикова, Н. П. (2015). Основные характеристики и взаимосвязи народной культуры. Известия Саратовского университета. Новая серия. Серия Философрия. Психология. Педагогика, 15(4), 32-37.

Непомнящих, Е. А. (2014). Язык и культура сегодня. Вестник Иркутского государственного технического университета, 6(89), 271-275.

Овчинников, Е. (1994). История джаза. https://ale07.ru/music/notes/song/jazz/ ovchinnikov2.htm

Перинская, Н. А. (2005). Ресоциализация. Знание. Понимание. Умение, 4, 161-162.

Сердюк, І. Л. (2006). Соціальна творчість як об'єкт діяльності особистості. Гуманітарний вісник Запорізької державної інженерної академії, 26, 84-93.

Смелзер, Н. (1994). Социология. Феникс.

Стернс, М. (1970). История джаза. Studfile.net. https://studfiles.net/preview/5147165/ page:5/

Шушарджан, С. В. (2005). Руководство по музыкальное терапии. Медицина.

Яковлева, Е. А., \& Кубасова, Э. Т. (2011). Концепт «джаз» и его становление в современном русском языке: проблема соотнесенности музыки и речи. Вестник Башкирского университета, 16 (1), 65-68.

\section{- References}

Alekseeva, A. A. (2018). Istoki vozniknoveniya blyuza i ego rasprostranenie [The origins of the blues and its spread]. Studencheskaya nauka i XXI vek, 2-2, 14-16 [in Russian].

Andreeva, G. M. (2001). Sotsial'naya psikhologiya [Social Psychology]. Aspekt Press [in Russian].

Bykhovskii, K. B. (2004). Muzyka v sovremennykh sotsial'nykh diskursakh: printsipy $i$ osnovnye vektory kul'turologicheskogo analiza [Music in Contemporary Social Discourses: Principles and Main Vectors of Culturological Analysis] [Extended abstract of candidate's thesis, Moscow Pedagogical State University] [in Russian].

Collier, D. L. (1984). Stanovlenie dzhaza [The Rise of Jazz]. Raduga [in Russian].

Dokuchaeva, M. N. (2020, March 10). Muzykal'nyi fenomen blyuza [The musical phenomenon of the blues]. In L. M. Artamonova, V. I. Ionesov, \& M. V. Kurmaev (Eds.), Natsional'noe kul'turnoe nasledie Rossii: regional'nyi aspect [National Cultural Heritage of Russia: Regional Aspect], Proceedings of the VIII All-Russian Scientific and Practical Conference, Samara (pp. 256-260). Samara State Institute of Culture [in Russian].

Efimov, A. V. (1958). Ocherki istorii SShA 1492-1870 [Essays on the History of the United States 1492-1870]. Uchpedgiz [in Russian]. 
Horlacha, M., Kremenia, V., \& Rybalka, V. (2000). Filosofiia [Philosophy]. Konsum [in Ukraine]. Konen, V. D. (1984). Rozhdenie dzhaza [The Birth of Jazz]. Sovetskii kompozitor [in Russian]. Kovalenko, T. M. (2009). Tvorchist i kreatyvnist - rysy maibutnikh fakhivtsiv u vyshchii ekonomichnyi osviti [Creativity - the features of future professionals in higher economic education]. Visnyk NTUU "KPI". Filosofiia. Psykholohiia. Pedahohika, 3(27), 2, 35-41 [in Ukraine].

Kovalev, V. G. (2015). Tipy sotsial'nogo vzaimodeistviya i sotsial'noe tvorchestvo [Types of social interaction and social creativity]. Vestnik Moscow City Teachers' Training University. Series Philosophical Sciences, 2(14), 30-41 [in Russian].

Kovalev, V. G. (2016). Rol' iskusstva v sotsial'nom tvorchestve [The role of art in social creativity]. Pedagogy of Art, 2, 25-30 [in Russian].

Lysikova, N. P. (2015). Osnovnye kharakteristiki i vzaimosvyazi narodnoi kul'tury [The main characteristics and relationships of folk culture]. Izvestiya of Saratov University. Philosophy. Psychology. Pedagogy, 15(4), 32-37 [in Russian].

Nepomnyashchikh, E. A. (2014). Yazyk i kul'tura segodnya [Language and culture today]. Proceedings of Irkutsk State Technical University, 6(89), 271-275 [in Russian].

Ovchinnikov, E. (1994). Istoriya dzhaza [Jazz History]. https://ale07.ru/music/notes/song/jazz/ ovchinnikov2.htm [in Russian].

Perinskaya, N. A. (2005). Resotsializatsiya [Re-socialisation]. Knowledge. Understanding. Skill, 4, 161-162 [in Russian].

Serdiuk, I. L. (2006). Sotsialna tvorchist yak ob'iekt diialnosti osobystosti [Social creativity as an object of specialisation]. Humanities Bulletin of Zaporizhzhe State Engineering Academy, 26, 84-93 [in Ukraine].

Shushardzhan, S. V. (2005). Rukovodstvo po muzykal'noe terapii [Music therapy guide]. Meditsina [in Russian].

Smelser, N. J. (1994). Sotsiologiya [Sociology]. Feniks [in Russian].

Sterns, M. Istoriya dzhaza [Jazz History]. Studfile.net. https://studfiles.net/preview/5147165/ page:5/ [in Russian].

Vorob'ev, D. N. (2017). Deyatel'nost' organizatsii "Niagara" i poyavlenie negrityanskogo protestnogo dvizheniya $v$ SShA (1905-1909) [The activities of the organisation "Niagara" and the emergence of the Negro protest movement in the United States (1905-1909)]. The Bryansk State University Herald, 4(34), 50-57 [in Russian].

Vorob'ev, D. N. (2018). Natsional'naya afroamerikanskaya liga: na zare negrityanskogo protestnogo dvizheniya v SShA (1887-1894) [National African American League: At the Dawn of the Negro Protest Movement in the United States (1887-1894)]. Izvestiya of Saratov University. History. International Relations, 18(1), 84-89 [in Russian].

Yakovleva, E. A., \& Kubasova, E. T. (2011). Kontsept "dzhaz" i ego stanovlenie v sovremennom russkom yazyke: problema sootnesennosti muzyki i rechi [The concept of "jazz" and its formation in the modern Russian language: the problem of correlation between music and speech]. Bulletin of Bashkir University, 16(1), 65-68 [in Russian]. 


\section{- SOCIAL ASPECT OF THE BLUES EMERGENCE} AS A LEADING PHENOMENON OF AFRICAN-AMERICAN CULTURE OF THE $19^{\text {TH }}$ CENTURY

\section{- Yanina Zhurba}

- Head of the Zhurba\&Zhurba School of Jazz, ORCID: 0000-0002-8466-4888, e-mail: yanazhurba7@gmail.com, Centre of Culture and Arts of the Dniprovskyi District of Kyiv, Kyiv, Ukraine

\section{- Abstract}

The purpose of the article is to identify and study the social aspect of the emergence of the blues as a leading phenomenon of African-American culture of the $19^{\text {th }}$ century. The research methodology is based on the use of universal scientific methods, namely system analysis, comparison, and generalisation, which provided a diverse study of the object and subject of research. The scientific novelty of the article lies in the fact that the social aspect of the emergence of the blues as a leading phenomenon of African-American culture of the 19 century was highlighted in the context of cultural studies for the first time. Conclusions. The study reveals that the social aspect plays a leading role in the emergence of the blues. Historical conditions have led to the formation of the specific characteristics of the social processes that were of great importance in the context of the existence of the African-American community of the nineteenth century in the United States. The article demonstrates that the changes in the social space after the official abolition of slavery became the catalyst for the birth of the new forms in African-American culture. The specific nature of these social processes consisted in the peculiarities of the resocialisation of African Americans in the US society, social isolation, which greatly suppressed the phenomenon of social creativity in the African-American environment, the aspect of permanent resistance and struggle of African Americans for their rights in American society, which contributed to the preservation of the constancy of characteristic elements of African-American culture. These characteristics contributed to the identification of AfricanAmerican culture against the background of the culture of the United States and subsequently of world culture. It is this aspect that should be identified as the main reason for the widespread and influence of the phenomena of African-American culture, in particular blues, on the emergence and formation of the dominant layer of musical culture, which is defined as non-academic music of the twentieth century.

Keywords: African-American culture of the 19th century; blues; preconditions of origin; social aspect 


\section{- СОЦИАЛЬНЫЙ АСПЕКТ ВОЗНИКНОВЕНИЯ БЛЮЗА КАК ВЕДУЩЕГО ЯВЛЕНИЯ АФРОАМЕРИКАНСКОЙ КУЛЬТУРЫ ХІХ ВЕКА}

\section{- Журба Янина Алексеевна}

- Руководитель Школы джаза Владимира и Яны Журбы, ORCID: 0000-0002-8466-4888, e-mail: yanazhurba7@gmail.com, Центр культуры и искусств Днепровского района г. Киева, Киев, Украина

\section{- Аннотация}

Цель статьи - выявить и исследовать социальный аспект возникновения блюза как ведущего феномена афроамериканской культуры XIX в. Методологическая база исследования основывается наприменении универсальных научных методов-системного анализа, сравнения и обобщения, что обеспечило разноплановое изучение объекта и предмета исследования. Научная новизна работы заключается в том, что социальный аспект возникновения блюза как ведущего явления афроамериканской культуры XIX в. впервые освещен в контексте культурологии. Выводы. В исследовании установлено, что социальный аспект играет доминирующую роль в процессе возникновения блюза. Исторические условия стали причиной формирования специфических характеристик социальных процессов, имевших большое значение в контексте бытия афроамериканской общины XIX в. на территории США. Установлено, что именно изменения в социальном пространстве, которые произошли после официальной отмены рабства, стали катализатором рождения новых форм в афроамериканской культуре. Специфика указанных социальных процессов заключалась в особенностях ресоциализации афроамериканцев в обществе США, социальной изоляции, которая угнетала явление социального творчества в афроамериканской среде, аспекте перманентного сопротивления и борьбы афроамериканцев за свои права в американском социуме, что способствовало сохранению устойчивости характерных элементов афроамериканской культуры. Указанные характеристики способствовали выделению афроамериканской культуры на фоне культуры США, а в дальнейшем и мировой культуры. Именно этот аспект необходимо определить как главную причину широкомасштабного распространения и влияния явлений афроамериканской культуры, в частности блюза, на образование и становление доминирующего пласта музыкальной культуры, который определяется как неакадемическая музыка XX в.

Ключевые слова: афроамериканская культура XIX в.; блюз; предпосылки возникновения блюза; социальный аспект 